\title{
An aqueous extract of Pfaffia sp. does not alter the labeling of blood constituents with technetium-99m and the morphology of the red blood cells
}

\author{
Joelma F. de Oliveira Fernandes ${ }^{1,3}$, Lavínia de Carvalho Brito ${ }^{1}$, Jacques N.G. Frydman', \\ Sebastião D. Santos-Filho', Mario Bernardo-Filho*1,2 \\ ${ }^{1}$ Universidade do Estado do Rio de Janeiro, Instituto de Biologia Roberto Alcantara Gomes, Departamento de \\ Biofísica e Biometria, Laboratório de Radiofarmácia Experimental, Av. 28 de setembro, 20551-030, \\ Rio de Janeiro, RJ, Brasil, \\ ${ }^{2}$ Instituto Nacional de Câncer, Coordenadoria de Pesquisa Básica, Praça Cruz Vermelha, \\ 20230-130, Rio de Janeiro, RJ, Brasil, \\ ${ }^{3}$ Universidade Estácio de Sá, Centro de Ciências da Saúde, Faculdade de Fisioterapia, Campus Niterói, \\ 22710-560, Rio de Janeiro, Brasil
}

\begin{abstract}
Plants have been used for the human beings as food, as additives and/or as medicines. There are controversies about the biological effects of several natural products and, it is worthwhile to try to develop experimental assays to evaluate properties of extracts of plants. Pfaffia sp. is utilized in popular medicine and various properties have been attributed to its extract. Red blood cells (RBC) and plasma proteins are labeled with technetium-99m (Tc-99m) and this labeling procedure depends on a reducing agent and stannous ion is usually used. There are reports that drugs can alter the labeling of blood elements with Tc-99m. We have evaluated the influence of a Pfaffia sp. extract on the labeling of blood constituents with Tc-99m and on the morphology of RBC. Blood was incubated with an aqueous extract of Pfaffia sp., stannous chloride and Tc-99m. Samples were centrifuged and plasma and blood cells were separated and also precipitated with trichloroacetic acid. Soluble and insoluble fractions were separated. The results did not show alteration in the uptake of radioactivity and no modifications on the shape of the RBC in presence of Pfaffia sp. Once this labeling process depends on a reducing agent, probably, this extract has compounds with anti-oxidant properties as already described elsewhere, that could protect the stannous ions against the oxidation process. This fact would aid the labeling process of blood elements with Tc-99m.
\end{abstract}

Keywords: Pfaffia, red blood cells, anti-oxidant properties, plasma proteins, technetium-99m.

\section{INTRODUCTION}

The use of natural products, as the medicinal plants, has increased in all over the world. Medicinal plants are used for the human being however several biological effects and the consequences for the health have not been well established yet. Many plants contain active substances that can induce biological effects and their frequent use has been correlated with a high incidence of diseases or undesired biological effect in the population (Nguyen et al., 1989; Subiza et al., 1991; Fonseca et al., 1994). However, various active compounds derived from medicinal plants have been assessed for their efficacy and tolerability in the treatment of breast cancer and have been evaluated in clinical trials (Mantle et al., 2000). Protective effect on radiation-induced deoxyribonucleic acid (DNA) double strand breaks and anti-oxidant activities have also attributed to the medicinal plants (Kim et al., 1996; Keum et al., 2000).

In nuclear medicine, examinations using radiopharmaceuticals provide a different kind of information that is supplied by other medical procedure, as X-ray radiography or sectional imaging techniques (computer tomography and magnetic resonance imaging). For diagnostic purposes, radionuclides that emit gamma radiation, such as technetium-99m (99mTc) are widely used. 99mTc has been the most utilized radionuclide in diagnosis nuclear medicine procedures to label compounds and cellular structures used as radiopharmaceuticals (Hladik III et al., 1987; Early \& Sodee, 1995; Saha, 1998; Nigri et al., 2004). It has also been used to label biological structures (Plotkowski et al., 1993; Bernardo-Filho et al., 1992; Bernardo-Filho et al., 1993; Marques et al., 2004) in basic scientific research. This wide use of this radionuclide is due to its optimal physical characteristics, availability from $99 \mathrm{Mo} / 99 \mathrm{mTc}$ generator and negligible environmental impact (Hladik III et al., 1987; Early; Sodee, 1995; Saha, 1998).

There are many applications of $99 \mathrm{mTc}$-labeled red blood cells (RBC) (Hladik III et al., 1987; Early; 


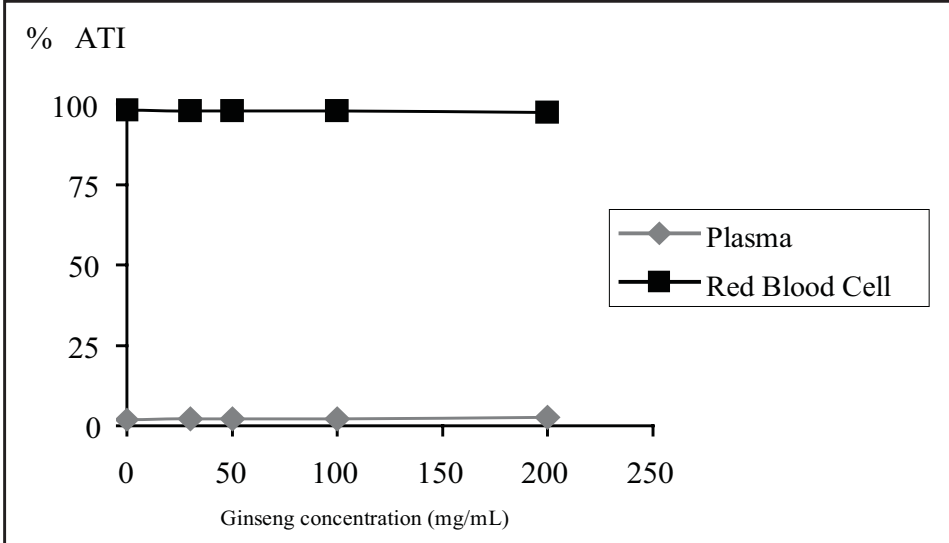

Figure 1. Effect of Pfaffia sp. extract on the labeling of red blood cells and plasma with 99mTc.

Samples of heparinized blood were incubated with different concentrations of Pfaffia sp. extract (20.0; 30.0; 50.0; 100.0 and $200.0 \mathrm{mg} / \mathrm{mL})$. A sample of whole blood was incubated with saline solution $(\mathrm{NaCl} 0.9 \%)$ as control. Then, stannous chloride $(1.2 \mu \mathrm{g} / \mathrm{mL})$ and $99 \mathrm{mTc}$, as sodium pertechnetate were added. The radioactivity in plasma and red blood cells was determined in a well counter and the \% of radioactivity (\%ATI) was calculated. A statistical analysis (ANOVA test, $\mathrm{n}=10$ ) was used to compare the values found.

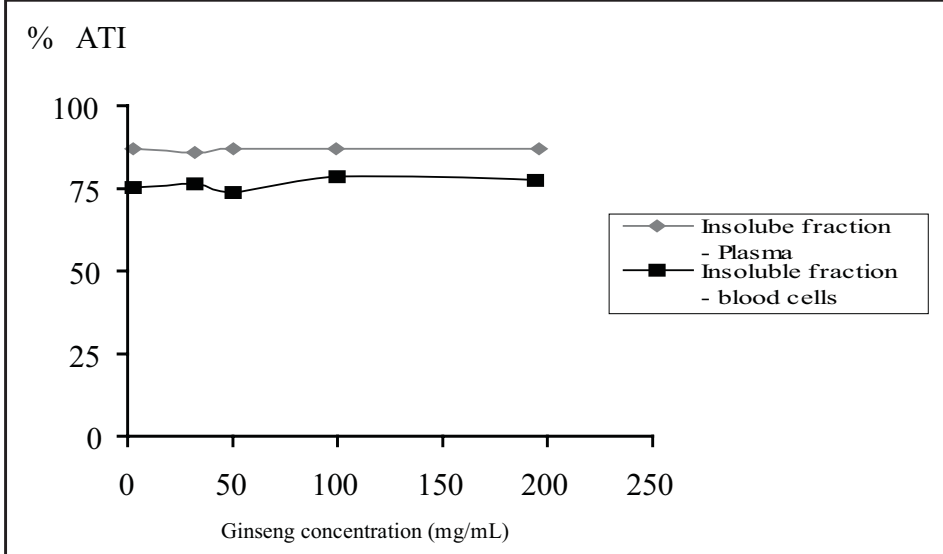

Figure 2. Effect of Pfaffia sp. extract on the labeling of the insoluble fractions from red blood cells and plasma with 99mTc.

Samples of heparinized blood were incubated with different concentrations of Pfaffia sp extract (20.0; 30.0; 50.0; 100.0 and $200.0 \mathrm{mg} / \mathrm{mL})$. A sample of whole blood was incubated with saline solution $(\mathrm{NaCl} 0.9 \%)$ as control. Then, stannous chloride $(1.2 \mu \mathrm{g} / \mathrm{mL})$ and $99 \mathrm{mTc}$, as sodium pertechnetate were added. These samples were centrifuged and plasma and blood cells were separated. Samples ( $20 \mu \mathrm{L})$ of plasma and red blood cells were precipitated with trichloroacetic acid $5 \%$ and soluble and insoluble fractions were separated. The radioactivity in soluble and insoluble fractions of plasma was determined in a well counter and the \% of radioactivity was calculated. A statistical analysis (ANOVA test, $\mathrm{n}=10$ ) was used to compare the values found. 
Sodee, 1995; Saha, 1998; Schillaci et al., 2004). RBC had been labeled with this radionuclide for in vitro, in vivo or in vivo/in vitro techniques. This labeling depends on a reducing agent and stannous ion $\left(\mathrm{Sn}^{2+}\right)$ is usually used. When whole blood is used in the labeling of RBC with $99 \mathrm{mTc}$, radioactivity is mainly found inside of RBC (beta-chain of the hemoglobin). However, it is also bound outside of the red blood cells on plasma proteins. This labeling process depends on optimal stannous chloride concentration, and stannous and pertechnetate ions across the erythrocyte membrane. The band-3 anion transport system and calcium channels may be the ways that $99 \mathrm{mTc}$ and $\mathrm{Sn}^{2+}$ ions have, respectively, to reach the interior of the RBC (Dewanjee, 1994; Callahan; Rabito, 1990; Bernardo-Filho et al., 1992; Gutfilen et al., 1992).

Many drugs (patient medications) have been reported to affect the labeling of blood constituents with 99mTc (Hladik III et al., 1987; Hesslewood; Leung, 1994; Nigri et al., 2002; Frydman et al., 2004), or the labeling conditions (Srivastava; Straub, 1992; Bernardo-Filho et al., 1994; Sampson, 1996) or the presence of extracts of medicinal plants (Oliveira et al., 1997; Vidal et al., 1998; Oliveira et al., 2000; Oliveira et al., 2003a). Therapy with $\beta$-adrenergic blockers, calcium channel blockers or nitrate may result in normal exercise radionuclide ventrilograms even in the presence of significant coronary artery disease. Thus, the presence of the disease may be missed and/or understimated (Hesslewood; Leung, 1994).

Pfaffia sp. is a large, scrambling, shrubby ground vine which has an intricate and deep root system. It is indigenous from the Amazon basin area and other tropical parts of Brazil, Ecuador, Panama, Paraguay, Peru and Venezuela. Since its first botanical recording in 1826, it has been referred to by several botanical names including

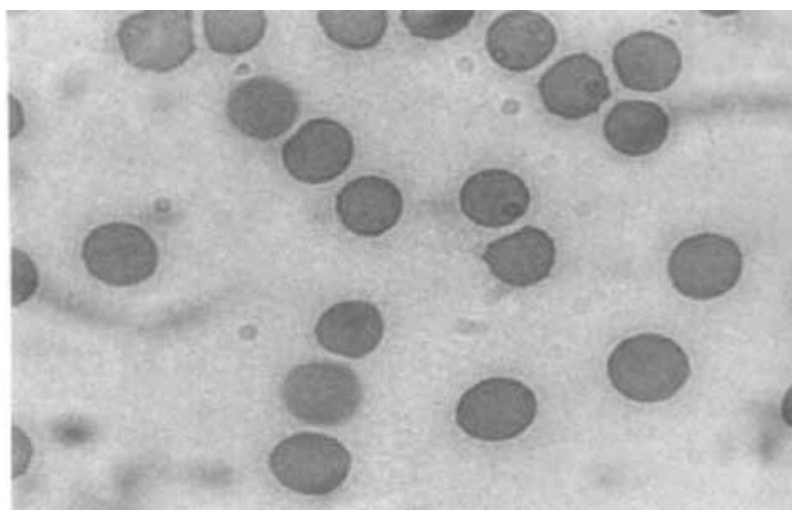

Figure 3. Photomicrography of blood smears prepared with samples of whole blood used to label RBC with $99 \mathrm{mTc}$ (control).

Samples of whole blood were incubated with $\mathrm{NaCl} 0.9 \%$ solution for $60 \mathrm{~min}$. After that, stannous chloride solution was added and the incubation continued for 1 hour. Then, 99mTc, as sodium pertechnetate was added. Blood smears were prepared, dried, fixed and staining. After that, the morphology of the red blood cells was evaluated under optical microscope (x1000).
Pfaffia paniculata, Hebanthe paniculata and Gomphrena paniculata. The genus Pfaffia sp. is well known in Central and South America with over 50 species of Pfaffia sp. growing in the warmer tropical regions of the area. The common names of Pfaffia sp. are Suma, Ginseng, Pfaffia, Para Toda and Corango (Gemtchújnicov, 1976; Joly, 1987).

In herbal medicine, many important properties and actions have been attributed to Pfaffia sp., as anabolic, analgesic, anti-inflammatory, antimutagenic, aphrodisiac, estrogenic, hypocholesterolemic, immunostimulant, nutritive, sedative, steroidal and tonic. Moreover, in Ecuador, it is considered a tonic for the cardiovascular system, the central nervous system, the reproductive system, and the digestive system and is used to treat hormonal disorders, sexual dysfunction and sterility, arteriosclerosis, diabetes, circulatory and digestive disorders, rheumatism, and bronchitis. In European herbal medicine it is used as to restore nerve and glandular functions, to balance the endocrine system, to strengthen the immune system, for infertility, menopausal and menstrual symptoms, for high cholesterol, to neutralize toxins and as a general restorative tonic after illness. In North and South American herbal medicine Suma root is used as an adaptogenic and regenerative tonic regulating many systems of the body, as an immunostimulant, and it is also used to treat exhaustion resulting from Epstein-Barr disease and Chronic Fatigue Syndrome, hypoglycemia, arthritis, anemia, tumors, high blood pressure and many types of stress (Gemtchújnicov, 1976; Joly, 1987; Mantle et al., 2000).

In spite of these applications of Pfaffia sp., undesired effect of this medicinal plant has also been reported. Subiza et al. (1991) described that a patient

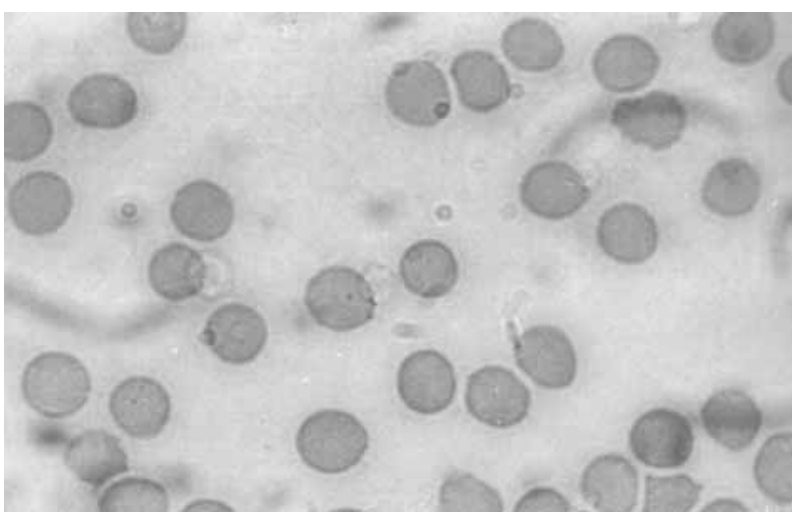

Figure 4. Photomicrography of blood smears prepared with samples of whole blood used to label RBC with 99mTc (blood samples were previously treated Pfaffia sp. extract $30 \mathrm{mg} / \mathrm{mL}$ ). Samples of whole blood were incubated with Pfaffia sp. extract (30 mg/mL) for 1 hour. After that, stannous chloride solution was added and the incubation continued for 1 hour. Then, $99 \mathrm{mTc}$, as sodium pertechnetate was added. Blood smears were prepared, dried, fixed and staining. After that, the morphology of the red blood cells was evaluated under optical microscope (x1000). 


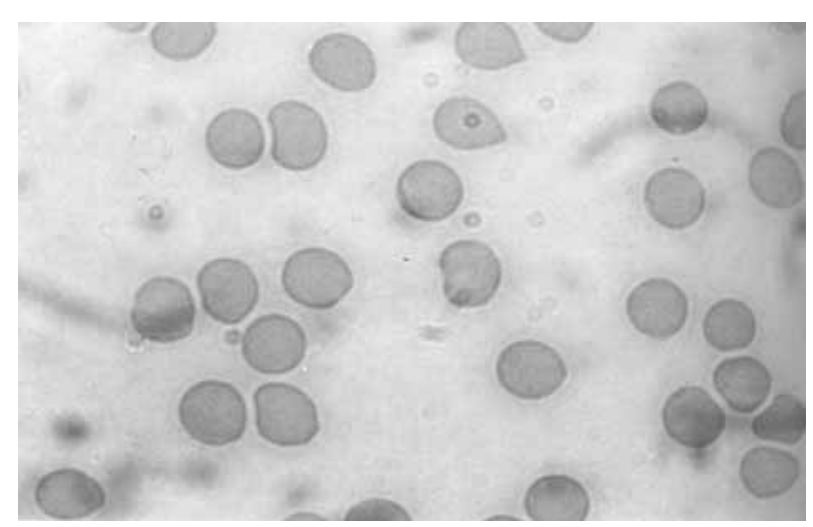

Figure 5. Photomicrography of blood smears prepared with samples of whole blood used to label RBC with 99mTc (blood samples were previously treated Pfaffia sp. extract $200 \mathrm{mg} /$ $\mathrm{mL}$ ).

Samples of whole blood were incubated with Pfaffia sp extract (200 mg/mL) for 1 hour. After that, stannous chloride solution was added and the incubation continued for 1 hour. Then, 99mTc, as sodium pertechnetate was added. Blood smears were prepared, dried, fixed and staining. After that, the morphology of the red blood cells was evaluated under optical microscope (x1000).

has developed symptoms of asthma after exposure to Pfaffia paniculata root powder used in the manufacturing of Brazil ginseng capsules. Airway hyperreactivity was confirmed by a positive bronchial challenge to methacholine. Sensitivity to this dust was confirmed by immediate skin test reactivity and a positive bronchial challenge (immediate response). The same study performed with Korean ginseng (Panax ginseng) elicited negative results.

The labeling of blood constituents with 99mTc has also used successfully to study the effect of extract of medicinal plants and we are trying to combine these results to improve an experimental model to evaluate properties of the plants used as food, additives or medicines. Authors have reported that tobacco (Vidal et al., 1998), Maytenus ilicifolia (Oliveira et al., 2000), Fucus vesiculosus (Oliveira et al., 2003a), Coffea arabica (Oliveira et al., 2003b), phytic acid (Lima-Filho et al., 2003), Mentha crispa (Santos-Filho et al., 2004) and Gingko biloba (Moreno et al., 2004) decrease the referred labeled process. Peumus boldus (Reineger et al., 1999) and Sechium edule do not decrease this labeling process (Diré et al., 2004). In this work, we have evaluated the influence of a Pfaffia sp. extract on the labeling of $\mathrm{RBC}$ and plasma proteins with 99mTc using an in vitro (Bernardo-Filho et al., 1983; Bernardo-Filho et al., 1990; Oliveira et al., 2000) technique.

\section{MATERIAL AND METHODS}

An in vitro technique used to label blood constituents (Bernardo-Filho et al., 1983; Oliveira et al., 2000) is described elsewhere and in these experiments was slightly modified. These experiments were performed without sacrificing the animals. Heparinized whole blood was withdrawn from Wistar rats. Samples $(0.5 \mathrm{~mL})$ were incubated with different concentrations of a commercial Pfaffia sp. (Herbarium, Laboratório Botânico, LTDA, Brazil) preparation (20, 30, 50, 100 and $200 \mathrm{mg} / \mathrm{mL})(100 \mu \mathrm{L})$ for 1 hour at room temperature. A sample of heparinized whole blood was incubated with saline solution ( $\mathrm{NaCl} 0.9 \%$ ) as control. Then, $0.5 \mathrm{~mL}$ of stannous chloride solution $(1.2 \mu \mathrm{g} / \mathrm{mL})$ was added and the incubation continued for another 1 hour. After this period of time, $99 \mathrm{mTc}(0.1 \mathrm{~mL})$, as sodium pertechnetate, recently milked from a 99Molibdenium/99mTechnetium generator (Instituto de Pesquisas Energéticas e Nucleares, Comissão Nacional de Energia Nuclear, Brasil), was added and the incubation continued for another $10 \mathrm{~min}$. These samples were then centrifuged and plasma $(\mathrm{P})$ and blood cells (BC) were separated. Samples $(20 \mu \mathrm{L})$ of $\mathrm{P}$ and $\mathrm{BC}$ were also precipitated with $1 \mathrm{ml}$ of trichloroacetic acid (TCA) 5\% and soluble (SF) and insoluble fractions (IF) were separated. The radioactivity in P, BC, IF-P, SF$\mathrm{P}, \mathrm{IF}-\mathrm{BC}$ and SF-BC were determined in a well counter (Automatic Gamma Counter, C5002, Packard, Canada). After that, the \% of radioactivity (\% ATI) was calculated, as previously described. A statistical analysis (ANOVA test, with significance level $\mathrm{p}=0.05, \mathrm{n}=10$ ) was utilized to compare the results obtained.

Histological preparations were carried out with blood samples treated with the Pfaffia sp. preparation for 60 min (room temperature). Blood smears were prepared, dried, fixed and staining. After that, the morphology of the red blood cells was evaluated under optical microscope.

\section{RESULTS}

Figure 1 shows the distribution of the radioactivity in plasma and red blood cells from blood treated with different concentrations of Pfaffia sp. solutions. Furthermore, the radioactivity is mainly found in the cells. The analysis of the results indicates that there is no significant decrease in the uptake of $99 \mathrm{mTc}$ by the red blood cells, independent on the concentration of the extract.

Figure 2 shows the fixation of the radioactivity in the insoluble fraction of plasma and red blood cells obtained from whole blood treated with different concentrations of Pfaffia sp. Moreover, the radioactivity is mainly found in the insoluble fractions of the plasma and cells. The analysis of the results indicates that there is no significant decrease in the fixation of $99 \mathrm{mTc}$ in plasma proteins independent on the concentration of the medicinal plant.

The qualitative comparison of the shape of the RBC (no treated and treated with the natural extracts) under optical microscopy has revealed no important morphological alterations due to the treatment of blood with Pfaffia sp extract in all the concentrations. In figure

Rev. Bras. Farmacogn Braz J. Pharmacogn. 15(2):abr/jun. 2005 
3 is shown the histological preparation of a sample of blood (control- no treated) and in figure 4 and 5 are shown the histological preparations of blood treated with Pfaffia sp. extract in the concentrations of 30 and $200 \mathrm{mg} / \mathrm{mL}$, respectively.

\section{DISCUSSION}

As there is not a well-established and general model to study the interaction of xenobiotic drugs (natural or synthetic) with radiopharmaceuticals, we are trying to develop a model to evaluate these phenomena. We are using two models, one based in the effect of drugs on the biodistribution of radiopharmaceuticals (Mattos et al., 1999) and other, concerning to the influence of drugs, mainly extracts of medicinal plants on the labeling of the blood constituents (Reineger et al., 1999; Oliveira et al., 2000, Santos-Filho et al., 2004). Here, we have studied the effect of the Pfaffia sp. extract on the labeling of red blood cells with 99mTc and in the fixation of this radionuclide to insoluble fractions of plasma (plasma proteins) and blood cells (blood cells proteins).

Although Pfaffia sp extracts are used in popular medicine, undesirable biological effects have also been attributed to the Pfaffia sp. (Subiza et al., 1991). Watanabe et al. (2000) have reported that Pfaffia paniculata (Brazilian ginseng) administered subcutaneously and intraperitoneally inhibits growth of allogeneic cancer cells in mice and in female AKR/J mice, oral doses of powdered roots from $P$. paniculata three times a week for 8 weeks; suppressed the enlargement of thymic lymphoma.

Kim et al. (1996) have examined the effect of ginseng on the induction and repair of gamma-rayinduced DNA double strand breaks (dsb) using neutral filter elution technique at $\mathrm{pH} 9.6$ in cultured murine spleen lymphocytes and they have shown that ginseng water extract presented a protective effect against the formation of dsb when it was used for 48 hours before 100 Gy gamma-ray-irradiation. Probably this protective effect of ginseng could be explained through a scavenger action of this medicinal plant against the reactive oxygen species (ROS) generated by the gamma rays. Keum et al. (2000) have also shown an antioxidant and anti-tumor promoting activities of the methanol extract of heatprocessed ginseng.

Biological effects of many medicinal plants have been attributed to the generation of ROS (Fonseca et al., 1994; Oliveira et al., 2000). Some of these effects have been abolished by the treatment of the biological system with ROS scavenger, as catalase, thiourea and superoxide dismutase, as it is the case with the genotoxic effect of guarana (Fonseca et al., 1994).

Our results show no alteration in the uptake of radioactivity for all the studied fractions isolated from the whole blood treated with Pfaffia sp., independently on the concentration of the extract of this medicinal plant. Pfaffia sp. extracts were not also capable to promote qualitative modifications on the shape of the RBC. Once this labeling process, depend on a reducing agent, probably the extract of Pfaffia sp. has compounds with anti-oxidant properties as already described for another authors (Kim et al., 1996; Keum et al., 2000), that could protect the stannous ions against the oxidation process. This fact would aid the labeling process of blood elements with Tc-99m.

It is always important have in mind that care must be taken when attempting to extrapolate experimental data to the clinical situation, once the observed effects may depend on the amount and/or nature of the drug. Our results permit to conclude that, the labeling of RBC with $99 \mathrm{mTc}$ can not be altered in presence of an extract of Pfaffia sp. Similarly, the fixation of radioactivity in the insoluble fraction of the RBC and PP is not modified, at least, when an in vitro technique to label RBC is used. Moreover, it is possible to speculate that the chemical compounds of the extract of Pfaffia sp could be used in the nuclear medicine as protecting agents against the stannous ion oxidations. Experiments are ongoing to try to identify the action mechanism of this extract of Pfaffia sp.

In conclusion, as reported to the tobacco extract (Vidal et al., 1998), Maytenus ilicifolia (Oliveira et al., 2000), Fucus vesiculosus (Oliveira et al., 2003a), Coffea arabica (Oliveira et al., 2003b), Mentha crispa (SantosFilho et al., 2004) and Gingko biloba (Moreno et al., 2004) when the histological alterations of the red blood cells could be the responsible by the modifications on the labeling of the RBC with $99 \mathrm{mTc}$, the results obtained with the qualitative comparison of the shape of the RBC (no treated and treated with natural extracts) under optical microscopy could justify the no modifications in the uptake of $99 \mathrm{mTc}$ by the red blood cells in presence of Pfaffia sp. extract.

\section{ACKNOWLEDGMENTS}

The authors thank the CNPq (Conselho Nacional de Pesquisa e Desenvolvimento) the financial support.

\section{REFERENCES}

Bernardo-Filho M, Gutfilen B, Caniné M.S, Boasquevisque E.M, Hassón-Voloch A 1992. Selective splenic scintigraphy: a very simple technique. Acta Med Biol 40: 133-136.

Bernardo-Filho M, Gutfilen B, Maciel OS 1994. Effect of different anticoagulants on the labelling of red blood cells and plasma proteins with Tc-99m. Nucl Med Comm 15: 730-734.

Bernardo-Filho M, Moura INS, Boasquevisque EM 1983. 99mtechnetium-labeled red blood cells "in vitro". Arq Biol Tecnol 26: 455-461.

Bernardo-Filho M, Nogueira JF, Sturm JÁ, Boasquevisque EM 1990. Plasma proteins labeling with 99mtechnetium. Arq Biol Tecnol 33: 811-817. 
Bernardo-Filho M, Pires ET, Boasquevisque EM, HassónVoloch A 1993. Studies on the incorporation of 99mtechnetium to the platyhelmint Dugesia tigrina. Rivista di Parassitologia 44: 7-11.

Callahan RJ, Rabito CA 1990. Radiolabeling of erythrocytes with technetium-99m: role of band-3 protein in the transport of pertechnetate across the cell membrane. $J$ Nucl Med 31: 2004-2008.

Dewanjee MK 1974. Binding of 99mTc ion to hemoglobin. $J$ Nucl Med 15: 703-706.

Diré G, Lima EAC, Gomes ML, Moreno S, Marques MTQ, Jales RL, Bernardo-Filho M 2004. An in vitro study of a natural product (chayote): an analysis on the labeling of blood components with technetium-99m an on the morphology of DNA. J Food Tech 2: 71-75.

Early PJ, Sodee DB 1995. Principles and Practice of Nuclear Medicine. Toronto: Mosby, Year Book.

Fonseca CAS, Leal J, Costa SS, Leitão AC 1994. Genotoxic and mutagenic effect of guarana (Paullinia cupana) in prokaryotic organisms. Mutat Res 321: 165-173.

Frydman JNG, Oliveira MBN, Santos AEO, Fonseca AS, Santos R, Bernardo-Filho M 2004. Influence of methylxanthines on the labeling of blood elements with technetium-99m. Pakistan J Biol Sci 7: 521524.

Gemtchújnicov ID 1976. Manual de Taxinomia Vegetal Agronômica. São Paulo: Ceres.

Gutfilen B, Boasquevisque EM, Bernardo-Filho M 1992. Calcium channel blockers: interference on red blood cells and plasma proteins labeling with $99 \mathrm{mT}$. Rev Española Med Nucl 11: 195-199.

Hesslewood S, Leung E, 1994. Drug interactions with radiopharmaceuticals. Eur J Nucl Med 21: 348-356.

Hladik III WB, Saha GB, Study KT 1987. Essentials of nuclear medicine sciences. Sydney: Williams and Wilkins.

Joly AB 1987. Botânica - Introdução à taxinomia vegetal. São Paulo: National.

Keum YS, Park KK, Lee JM, Chun KS, Park JH, Lee SK, Kwon H, Surh YJ 2000. Antioxidant and anti-tumor promoting activities of the methanol extract of heatprocessed ginseng. Cancer Lett 150: 41-48.

Kim TH, Lee YS, Cho CK, Park S, Choi SY, Yool SY 1996. Protective effect of ginseng on radiation-induced DNA double strand breaks and repair in murine lymphocytes. Cancer Biother Radiopharms 11: 267272.

Lima-Filho GL, Freitas RS, Aleixo LCM, Moreno SRF, Catanho MTJA, Bernardo-Filho M 2003. Evaluation of the phytic acid effect on the labeling of blood elements with technetium-99m and on the survival of a strain of Escherichia coli treated with stannous fluoride. Mol Cell Biochem 247: 121-126.

Mantle D, Lennard TW, Pickering AT 2000. Therapeutic applications of medicinal plants in the treatment of breast cancer: a review of their pharmacology, efficacy and tolerability. Adverse Drug React Toxicol Rev 19: 223-240.

Marques RG, Petroianu A, Oliveira MB. Bernardo-Filho M, Portela MC 2004. Evaluation of possible failure of the mononuclear phagocyte after total splenectomy in rats. Braz Arch Biol Techn 47: 199-204.

Mattos DM, Gomes ML, Freitas RS, Rodrigues PC, Paula EF, Bernardo-Filho M 1999. Model to evaluate the biological effect of natural products: vincristine action on the biodistribution of radiopharmaceuticals in female Balb/c mice. J Appl Toxicol 19: 251-254.

Moreno SR, Freitas RS, Rocha EK, Lima-Filho GL, BernardoFilho M 2004. Protection of plasmid DNA by a Ginkgo biloba extract from the effects of stannous chloride and the action on the labeling of blood elements with technetium-99m. Braz J Med Bio Res 37: 267-271.

Nguyen T, Fluss L, Madej R, Ginther C, Leighton T 1989. The distribution of mutagenic activity in red, rose and white wines. Mutat Res 223: 205-212.

Nigri F, Oliveira MBN, Bernardo-Filho M 2002. Assessment of the effect of antiseizure drugs on the labeling process of red blood cells and plasma proteins with technetium-99m. Cell Mol Biol 48: 793-802.

Nigri F, Bernardo-Filho M, Telles C, Silva JW, Boasquevisque EM 2004. $99 \mathrm{~m}_{\text {Tc-DTPA ventriculocisternography }}$ for postoperative evaluation of endoscopic third ventriculostomy: A preliminary study model. Biomed Res 15: 138-141.

Oliveira JF, Braga ACS, Oliveira MB, Avila AS, Caldeira-DeAraujo A, Cardoso VN, Bezerra RJA, BernardoFilho M 2000. Assessment of the effect of Maytenus ilicifolia (Espinheira-santa) extract on the labeling of red blood cells and plasma proteins with technetium99m. J Ethnopharmacol 72: 179-184.

Oliveira JF, Oliveira MBN, Avila AS, Braga ACS, Catanho MTJ, Jales RL, Cardoso VN, Bernardo-Filho M 2003a. Assessment of the effect of Fucus vesiculosus extract on the labeling of blood constituents with technetium$99 \mathrm{~m}$ and the histological modifications on the shape of the red blood cells. Food Chem Toxicol 41: 15-20.

Oliveira JF, Santos-Filho SD, Catanho MTJ, Srivastava SC, Lima-Filho G, Bernardo-Filho M 2003b. Effect of extract of medicinal plant on the labeling of blood elements with technetium-99m and on the morphology of red blood cells (RBC): toxicological action of roast coffee beans (Coffea arabica). Indian J Nucl Med 18: 52-56.

Plotkowski MC, Bernardo-Filho M, Meirelles MN, Tournier JM, Puchelle E 1993. Pseudomonas aeruginosa binds to soluble cellular fibronectin. Curr Microbiol 26: 9195.

Reineger IW, Oliveira JF, Caldeira-De-Araújo A, BernardoFilho M 1999. Effect of Peumus boldus on the labeling of red blood cells and plasma proteins with technetium-99m. Int J Appl Radiat Isot 51: 145-149.

Saha GB. 1998. Fundamentals of nuclear pharmacy. New York: Springer-Verlag.

Sampson CB 1996. Complications and difficulties in radiolabelling blood cells: a review. $\mathrm{Nucl}$ Med Comm 17: 648-658.

Santos-Filho SD, Diré G, Lima E, Oliveira MN, Bernardo-Filho M 2004. Effect of Mentha crispa (mint) extract on the labeling of blood elements with technetium-99m: A possible evaluation of free radicals. J Biol Sci 4: 266-270.

Schillaci O, Danieli R, Manni C, Capocceetti S 2004. Technetium-99m-labelled red blood cell imaging in the diagnosis of hepatic haemangiomas: the role of SPCT/CT with a hydrid camera. Eur J Nucl Med Mol Imaging 31: 1011-1015.

Srivastava SC, Straub RF 1992. Evaluation of heparin and 
anticoagulant citrate dextrose in the preparation of technetium-99m-red blood cell with Ultra Tag RBC kit. Reply. J Nucl Med 33: 307-308.

Subiza J, Subiza JL, Escribano PM, Hinojosa M, Garcia R, Jerez M, Subiza J 1991. Occupational asthma caused by Brazil ginseng dust. J Allergy Clin Immunol 88: 731-736.

Vidal MV, Gutfilen B, Fonseca LM, Bernardo-Filho M 1998. Effect of the tobacco on the labeling of red blood cells and plasma proteins with technetium-99m. J Exp Clin Cancer Res 17: 41-46.

Watanabe T, Watanabe M, Watanabe Y, Hotta C 2000. Effects of oral administration of Pfaffia paniculata (Brazilian ginseng) on incidence of spontaneous leukemia in AKR/J mice. Cancer Detect Prev 24: 173-178. 